\title{
Kemampuan Berpikir Kreatif Siswa SMP kelas VII dalam Penyelesaian Masalah Statistika
}

\author{
Kiki Nia Sania Effendi, ${ }^{1, a}$ \\ Prodi Pendidikan Matematika, Universitas Singaperbangsa Karawang \\ aE-mail: qqeffendi@gmail.com \\ Ehda Farlina \\ Prodi Pendidikan Matematika, UIN Sunan Gunung Djati Bandung \\ Jl. AH Nasution No. 105 Cibiru Bandung, 40614 Indonesia
}

Dikirim: 15 Oktober 2017; Diterima: 08 November 2017; Dipublikasikan: 20 Desember 2017

\begin{abstract}
Abstrak. Tujuan dari penelitian ini yaitu untuk mengetahui bagaimanakah kemampuan berpikir kreatif siswa kelas VII SMP dalam penyelesaian masalah statistika. Pada penelitian ini kompetensi dasar pengetahuan yang digunakan adalah memahami teknik penataan data dari dua variabel menggunakan tabel, grafik batang, garis dan diagram lingkaran. Selanjutnya, kompetensi dasar keterampilan yang digunakan yaitu mengumpulkan, mengolah, menginterpretasi, dan menyajikan data hasil pengamatan dalam bentuk tabel, diagram, dan grafik. Penelitian ini merupakan penelitian kuantitatif metode deskriptif dengan teknik pengumpulan data melalui pemberian tes kemampuan berpikir kreatif bentuk uraian yang sebelumnya dilakukan validasi dari tes yang akan digunakan pada penelitian ini. Hasil penelitian ini menunjukan nilai hasil tes kemampuan berpikir kreatif siswa 26,7\% pada kategori tinggi, $63,3 \%$ pada kategori sedang dan $10 \%$ pada kategori rendah.
\end{abstract}

Kata Kunci. Kemampuan berfikir kreatif, Penyelesaian Masalah.

\section{Pendahuluan}

Kecakapan hidup merupakan hal yang perlu dikembangkan setiap individu dalam menghadapi tantangan hidup yang muncul dari adanya perkembangan zaman saat ini. Kecakapan hidup yang perlu dikembangkan untuk menjawab tantangan hidup tersebut salah satunya adalah kemampuan untuk berpikir kreatif.

Kemampuan berfikir kreatif yang memadai akan mampu membentuk individu-individu kreatif yang dapat menjawab tantangan 
globalisasi dunia sehingga mampu bersaing dalam kondisi apapun. Mindset kurikulum 2013 adalah ingin menciptakan manusia Indonesia yang kreatif" (Yani, 2014: 81). Hal tersebut didasari oleh adanya perkembangan zaman yang menuntut individu untuk dapat menghadapi persaingan global, sehingga seorang individu memiliki kemampuan untuk menciptakan ide atau gagasan baru yang diperoleh dari kemampuan berpikir kreatif. Menurut Pehkonen (Mahmudi, 2010), kreativitas tidak hanya terjadi pada bidangbidang tertentu, seperti seni, sastra, atau sains, melainkan juga ditemukan dalam berbagai bidang kehidupan termasuk matematika. Di dalam kerangka kompetensi abad 21 menunjukkan bahwa siswa harus memiliki keterampilan hidup dan karir, keterampilan belajar dan berinovasi (kritis dan kreatif), kemampuan memanfaatkan informasi dan berkomunikasi (Partnership for 21 st Century, 2009: 1). Dari uraian tersebut menunjukan pentingnya setiap individu untuk memiki kemampuan berpikir kreatif. Dengan demikian kemampuan berpikir kreatif penting dimiliki siswa dalam kegiatan pembelajaran matematika.

Tujuan pembelajaran matematika dalam kurikulum 2013 diantaranya: (1) siswa dapat memahami konsep matematika, yaitu menjelaskan keterkaitan antar konsep dan menggunakan konsep maupun algoritma, secara luwes, akurat, efisien, dan tepat, dalam pemecahan masalah; (2) siswa dapat menggunakan pola sebagai dugaan dalam penyelesaian masalah, dan mampu membuat generalisasi berdasarkan fenomena atau data; (3) siswa dapat menggunakan penalaran pada sifat, melakukan manipulasi matematika baik dalam penyederhanaan, maupun menganalisa komponen yang ada dalam pemecahan masalah; (4) siswa dapat mengomunikasikan gagasan, penalaran serta mampu menyusun bukti matematika dengan menggunakan kalimat lengkap, simbol, tabel, diagram, atau media lain untuk memperjelas keadaan atau masalah; Selanjutnya (5) siswa dapat memiliki sikap menghargai kegunaan matematika dalam kehidupan, yaitu memiliki rasa ingin tahu, perhatian, dan minat dalam mempelajari matematika, sikap ulet dan percaya diri dalam pemecahan masalah; (6) siswa dapat memiliki sikap dan perilaku yang sesuai dengan nilai-nilai dalam matematika dan pembelajarannya, seperti taat azas, konsisten, menjunjung tinggi kesepakatan, toleran, menghargai pendapat orang lain, santun, demokrasi, ulet, tangguh, kreatif, menghargai kesemestaan (konteks, lingkungan), tanggung jawab, adil, jujur, teliti, dan cermat; (7) siswa dapat melakukan 
kegiatan motorik menggunakan pengetahuan matematika; siswa dapat menggunakan alat peraga sederhana maupun hasil teknologi untuk melakukan kegiatan-kegiatan matematika (Kemendikbud, 2014: 328).

Pada kurikulum tersebut tertuang salah satu materi yang erat kaitannya dengan keseharian siswa yaitu materi statistika. Statistika merupakan salah satu materiyang dipelajari siswa kelas VII pada semester dua dengan kompetensi dasar pengetahuan memahami teknik penataan data dari dua variabel menggunakan tabel, grafik batang, garis dan diagram lingkaran serta kompetensi dasar keterampilan mengumpulkan, mengolah, dan menginterpretasi, dan menyajikan data hasil pengamatan dalam bentuk tabel, diagram, dan grafik.

Berpikir kreatif merupakan kemampuan yang sudah seharusnya dimiliki siswa dalam pembelajaran matematika. Kurikulum saat ini mengharapkan kegiatan pembelajaran yang menumbuhkan ide-ide matematika yang baru dan merupakan pemikiran siswa sehingga ide tersebut dapat menjadi solusi alternatif dalam penyelesaian masalah matematika. Selaras dengan pendapat Munandar (2012:35) mengatakan bahwa siswa yang kreatif biasanya mempunyai rasa humor yang tinggi, dapat melihat masalah dari berbagai sudut tinjau, dan memiliki kemampuan untuk bermain dengan ide, konsep, atau kemungkinan-kemungkinan hal yang dikhayalkan.

Kemampuan berpikir kreatif sangat diperlukan oleh siswa mengingat bahwa dewasa ini ilmu pengetahuan dan teknologi berkembang sangat pesat dan memungkinkan siapa saja bisa memperoleh informasi secara cepat dan mudah dari berbagai sumber di seluruh dunia (Arifani, Sunardi dan Setiawani, 2015: 161). Menurut Torraance (Jazuli, 2009) mengemukakan ciri berfikir kreatif antara lain: Fluency (kelancaran), Flexibility (keluwesan), Originality (keaslian), dan Elaboration (elaborasi).

Dalam pembelajaran matematika Fluency (kelancaran) terlihat dikuasai oleh siswa jika siswa mampu membangun banyak ide matematika sehingga menjawab pertanyaan dengan lancar. Flexibility (keluwesan) terlihat dikuasai siswa jika siswa mampu membangun ide matematika yang beragam dengan mencoba berbagai cara dalam memecahkan masalah matematika sehingga jawaban siswa tidak cenderung sama. Originality (keaslian) terlihat dikuasai siswa jika siswa mampu untuk menghasilkan ide-ide yang tidak umum sehingga jawaban siswa tidak terpaku pada 
materi yang dijelaskan oleh guru dan buku pegangan siswa. Elaboration (elaborasi) terlihat dikuasai siswa jika siswa mampu untuk mengembangkan ide matematika dalam penyelesaian masalah matematika secara detail. Berdasarkan uraian di atas mengenai pentingnya setiap siswa untuk memiliki kemampuan berpikir kreatif dalam pembelajaran matematika maka peneliti tertarik untuk menganalisis kemampuan erpikir kreatif siswa dalam menyelesaikan permasalahan matematika materi statistika.

\section{Metodologi Penelitian}

Penelitian ini merupakan penelitian kuantitatif dengan metode deskriptif. Subjek dalam penelitian ini adalah siswa kelas VII sebanyak 30 siswa di MTs Alfalah di Kabupaten Karawang. Data yang diperoleh berupa hasil tes kemampuan berpikir kreatif yang diolah dengan menghitung persentase dari skor yang diperoleh siswa pada masing-masing indikator kemampuan berpikir kreatif yang diinterpretasikan sebagai berikut:

Tabel 2.1

Interpretasi Tingkat Berpikir Kreatif Siswa (Riduwan, 2010: 41)

\begin{tabular}{|c|c|}
\hline Persentase & Interpretasi \\
\hline $81 \%-100 \%$ & Sangat Baik \\
\hline $61 \%-80 \%$ & Baik \\
\hline
\end{tabular}

\begin{tabular}{|c|c|}
\hline Persentase & Interpretasi \\
\hline $41 \%-60 \%$ & Cukup \\
\hline $21 \%-40 \%$ & Kurang \\
\hline $0 \%-20 \%$ & Sangat Kurang \\
\hline
\end{tabular}

Penentuan kecenderungan variabel kemampuan berpikir kreatif siswa dalam masalah yang berkaitan dengan statistika melalui kategorisasi yang didasari oleh nilai rata-rata dan standar deviasi. Siswa yang berada pada kategori tinggi siswa yang memperoleh nilai lebih dari nilai rata-rata yang dijumlahkan dengan standar deviasi.

Siswa yang berada pada kategori rendah siswa yang memperoleh nilai kurang dari selisih dari nilai rata-rata dengan standar deviasi. Sedangkan siswa yang berada pada kategori rendah siswa yang memperoleh nilai yang ada diantara nilai dikategori tinggi dan rendah (Arikunto,2010).

\section{Hasil dan Pembahasan}

Hasil yang diperoleh dalam penelitian ini berupa data hasil tes pada materi statistika untuk mengetahui kemampuan berpikir kreatif siswa. Adapun hasilnya sebagai berikut:

Tabel 3.1

Hasil Tes Kemampuan Berpikir Kreatif

\begin{tabular}{cccc}
\hline $\begin{array}{c}\text { Jumlah } \\
\text { siswa }\end{array}$ & \multicolumn{2}{c}{ Maks. } & Min. Rata-rata \\
\hline 30 & 85 & 60 & 72,5 \\
\hline
\end{tabular}


Berdasarkan tabel di atas menunjukan nilai rata-rata siswa 72,5 daro 30 orang siswa. selanjutnya, nilai maksimum yang diperoleh yaitu 85 dan nilai minimum sebesar 60. Untuk mengetahui seberapa besar persentase kemampuan berpikir kreatif siswa dari masing-masing indikator maka hasil jawaban siswa di analisis dengan mempersentasekan skor rata-rata yang diperoleh dari masing-masing indikator berpikir kreatif siswa lalu diinterpretasikan sangat baik, baik, cukup, kurang dan sangat kurang menurut Riduwan (2010: 41). Adapun hasilnya sebagai berikut:

Tabel 3.2

Interpretasi Kemampuan Berpikir Kreatif berdasarkan Indikator

\begin{tabular}{ccc}
\hline Indikator & Persentase & Interpretasi \\
\hline $\begin{array}{c}\text { Fluency } \\
\text { (kelancaran) }\end{array}$ & $80 \%$ & Baik \\
$\begin{array}{c}\text { Flexibility } \\
\text { (keluwesan) }\end{array}$ & $23,3 \%$ & Kurang \\
$\begin{array}{c}\text { Originality } \\
\text { (keaslian) }\end{array}$ & $35 \%$ & Kurang \\
$\begin{array}{c}\text { Elaboration } \\
\text { (elaborasi) }\end{array}$ & $63,3 \%$ & Baik \\
\hline
\end{tabular}

Ketercapaian siswa untuk tes kemampuan berpikir kreatif dari masing-masing indikator pada interpretasi baik dan kurang. Indikator Fluency (kelancaran) telah dimiliki oleh $80 \%$ siswa yang telah mampu menjawab dengan memperoleh skor maksimal pada indikator ini sehingga terinterpretasi baik. Indikator Flexibility (keluwesan) masih berada diinterpretasi kurang karena hanya $23,3 \%$ siswa yang telah mampu menjawab dengan memperoleh skor maksimal pada indikator ini. Interpretasi indikator Originality (keaslian) masih kurang karena siswa yang mampu menjawab dengan skor maksimal hanya 35\%. Pada indikator Elaboration (elaborasi) persentase mencapai $63,3 \%$ sehingga terinterpretasi baik. Jika persentase kemampuan berpikir kreatif ditinjau dari nilai keseluruhan berdasarkan kategorisasi dari nilai rata-rata dan standar deviasi (Arikunto, 2010) diperoleh hasil sebagai berikut:

Tabel 3.3

Tingkat Kemampuan Berpikir Kreatif Siswa

\begin{tabular}{|c|c|c|c|}
\hline Kategori & $\begin{array}{c}\text { Kriteria } \\
\text { Nilai }\end{array}$ & $\begin{array}{c}\text { Jumlah } \\
\text { Siswa }\end{array}$ & Persentase \\
\hline Tinggi & $\geq 76,6$ & 8 & 26,7 \\
\hline Sedang & $67,8<$ Nilai $<76,6$ & 19 & 63,3 \\
\hline Rendah & $<67,8$ & 3 & 10 \\
\hline
\end{tabular}

Berdasarkan tabel di atas menunjukan kemampuan berpikir kreatif siswa di dominasi oleh siswa yang berada pada kategori sedang dengan perolehan persentase sebesar $63,3 \%$ terdiri dari 19 orang siswa. Pada kategori tinggi hanya 8 siswa yang dipersentsekan sebesar $26,7 \%$. Selanjutnya, 3 orang siswa pada kategori rendah dengan persentse $10 \%$. 
Berdasarkan hasil penelitian pada uraian sebelumnya menunjukan kemampuan berpikir kreatif siswa belum sepenuhnya dimiliki oleh siswa yang ditunjukan dengan interpretasi siswa dari masing-masing indikator masih ada pada interpretasi kurang yaitu indikator flexibility (keluwesan) dan originality (keaslian). Padahal menurut Siswono (2011: 549) yang berpendapat bahwa indikator flexibility merupakan indikator terpenting kedua setelah aspek originality karena indikator flexibility ini menunjukkan produktivitas ide yang digunakan untuk menyelesaikan suatu masalah sedangkan indikator originality ditempatkan pada posisi tertinggi diantara indikator berpikir kreatif lainnya. Pada umumnya jawaban siswa yang belum memenuhi indikator flexibility (keluwesan) dan originality (keaslian) yaitu terlihat jawaban siswa cenderung sama dengan langkah-langkah dari contoh yang dijelaskan oleh guru sehingga tidak terlihat variasi jawaban siswa padahal siswa dapat menyelesaikan dengan beberapa cara yang berbeda dan tidak menunjukkan gagasan baru dari siswa dalam penyelesaian masalah tersebut. Indikator fluency ini merupakan aspek berpikir kreatif yang berada di urutan terendah jika dibandingkan dengan indikator flexibility dan originality (Siswono, 2011: 549).
Jika melihat persentasi pada indikator fluency (kelancaran) terlihat sudah didominasi oleh siswa yang mampu menjawab dengan perolehan skor maksimal persentasi sebesar $80 \%$ sedangkan pada indikator elaboration (elaborasi) 63,3\%. Meski demikian masih terdapat beberapa siswa yang tidak mencapai skor maksimal. Pada indikator Fluency (kelancaran) 20\% jawaban siswa belum memenuhi indikator ini terlihat dari jawaban siswa yang masih belum lancar dalam menentukan data dan menghitung nilai rata-rata dari data yang diketahui pada tabel sehingga siswa tersebut karena siswa hanya menuliskan banyaknya data dan menjumlahkan datadata yang ada pada tabel frekuensi sehingga tidak dapat pula menentukan banyaknya siswa yang ada di atas nilai rata-rata.

Pada indikator Elaboration (elaborasi) jawaban siswa yang belum memenuhi indikator ini hanya mampu menulis ulang data yang diketahui yang dikonversi menjadi data pada tabel frekuensi sehingga siswa tidak mampu menjawab secara rinci dalam penyelesaian masalah menyajikan data dalam sebuah diagram dan menentukan nama dari diagram tersebut serta tidak mampu menentukan nilai tertinggi dan terrendah yang diperoleh siswa berdasarkan ukuran sepatu. 


\section{Simpulan dan Saran}

Berdasarkan hasil temuan penelitian dan pembahasan mengenai kemampuan berpikir kreatif siswa kelas VII pada materi statistika menunjukan indikator kemampuan berpikir kreatif yang mampu dicapai oleh siswa dengan persentase tertinggi adalah indikator fluency dan persentase terrendah pada indikator flexibility sebesar 23,3\%. Secara keseluruhan berdasarakan hasil tes, indikator fluency dan elaboration terinterpretasi baik, indikator flexibility dan originality dapat dicapai dengan interpretasi kurang.

Tingkat kemampuan berpikir kreatif dari 30 orang siswa secara keseluruhan tercapai oleh 8 orang siswa pada kategori tinggi dengan persentase $26,7 \%, 19$ orang siswa pada kategori sedang dengan persentase $63,3 \%$ dan 3 orang siswa pada kategori rendah dengan persentase $10 \%$.

Berdasarkan hasil temuan pada penitian ini terdapat beberapa saran yang dapat peneliti sampaikan berdasarkan temuan dalam penelitian ini adalah :

a. Bagi siswa-siswi, hasil penelitian ini diharapkan dapat membantu siswa dalam menyadari kekurangan dan kelebihan ditinjau dari kemampuan berpikir kreatif sehingga siswa mampu meningkatkan bagian indikator yang masih belum dipenuhi oleh siswa.

b. Bagi guru, penelitian ini diharapkan dapat membantu guru dalam memahami kemampuan indikator berpikir kreatif siswa sehingga guru dapat mendesign pembelajaran yang dapat meningkatkan kemampuan berpikir kreatif siswa.

c. Bagi peneliti lainnya, diharapkan dapat melaksanakan penelitian lanjutan yang berpotensi untuk meningkatkan kemampuan berpikir kreatif siswa.

\section{Daftar Pustaka}

Arifani, N.H., Sunardi, dan Setiawani, S. 2015. Tingkat Kemampuan Berpikir Kreatif Matematika Siswa SMP Kelas VIII di SMPN 6 Jember, SMP AlFurqon, SMPN 1 Rambipuji dan SMP PGRI 1 Rambipuji". Jurnal Kadikma. Vol.6.

Arikunto, S. 2010. Prosedur Penelitian Suatu Pendekatan dan Praktik. Jakarta: PT Rineka Cipta.

Jazuli, A. 2009. Berpikir Kreatif dalam Kemampuan Berpikir Matematika. Makalah disajikan di Seminar Nasional Matematika dan Pendidikan Matematika pada 5 Desember 2009 (118-130), Yogyakarta (209-220).

Kemdikbud. 2014. Permendikbud Nomor 58 Tahun 2014 tentang Kurikulum 2013 SMP Mata Pelajaran Matematika. Jakarta: Kementrian Pendidikan dan Kebudayaan.

Mahmudi, A. 2010. Mengukur Kemampuan Berpikir Kreatif Matematis. Pendidikan Matematika FMIPA UNY Yogyakarta Makalah Disajikan Pada 
Konferensi Nasional Matematika XV

UNIMA Manado, 30 Juni - 3 Juli 2010 .

Munandar, U. 2012. Pengembangan Kreativitas Anak Berbakat. Jakarta: Rineka Cipta.

Partnership for 21st Century. 2009. Framework for 21 st Century Learning. [Online] tersedia: http:// www. p21.org/about-us/p21-framework.

Diakses pada 20 Mei 2017

Riduwan, 2010. Dasar-dasar Statistika. Bandung: Alfabeta.

Siswono, T.Y.E. (2011). Level Student's

Creative Thinking in Classroom. Academic Journal, 6 (7): 548-553.

Yani, A. (2014). Mindset Kurikulum 2013. Bandung: Alfabeta CV. 